\title{
Evaluation of Agronomic Management Practices on Farmers' Fields under Rice-Wheat Cropping System in Northern India
}

\author{
Dinesh Kumar Singh, Purushottam Kumar, and A. K. Bhardwaj \\ Department of Agronomy, G.B. Pant University of Agriculture \& Technology, Pantnagar, Uttarakhand 263 145, India \\ Correspondence should be addressed to Dinesh Kumar Singh; dkonweb@gmail.com
}

Received 26 June 2013; Accepted 12 November 2013; Published 30 January 2014

Academic Editor: Othmane Merah

Copyright (C) 2014 Dinesh Kumar Singh et al. This is an open access article distributed under the Creative Commons Attribution License, which permits unrestricted use, distribution, and reproduction in any medium, provided the original work is properly cited.

Rice (Oryza sativa L.)-wheat (Triticum aestivum L. emend. Fiori and Paol.) is the most important two crops a year intensive rice based cropping system of Asia. Agronomic management is the most important input for getting potential yield and high net returns in any crop or crop sequence. Most of the farmers used to grow old varieties of rice and wheat without any row arrangement. Fertilization is mainly limited to nitrogenous fertilizer only. Therefore, the present study was undertaken to find out the effect of different agronomic management practices on productivity and economics of rice-wheat system at farmers' fields. Inclusion of improved variety in rice and wheat incurred additional cost of $\$ 52 /$ ha and provided additional return of $\$ 101 /$ ha, whereas sowing/transplanting of rice and wheat in lines incurred additional cost of $\$ 30 /$ ha and resulted in additional returns of $\$ 146 / \mathrm{ha}$. Balanced fertilization incurred additional cost of $\$ 38$ over the imbalanced fertilization and provided additional returns of $\$ 180 /$ ha. Recommended package of practices (improved variety, line sowing/transplanting and balanced fertilization) incurred additional cost of cultivation of $\$ 120 /$ ha over the farmers' practice and achieved additional net returns of $\$ 426 / \mathrm{ha}$.

\section{Introduction}

Rice (Oryza sativa L.)-wheat (Triticum aestivum L. emend. Firori and Paol.) is the most important two crops a year intensive rice based cropping system of Asia; a third of the irrigated rice and half of the irrigated wheat in South Asia come from this cropping system $[1,2]$. Available estimates show that 12 million hectares ( $\mathrm{m}$ ha) of this cropping system exist in four countries of South Asia: $9.4 \mathrm{~m}$ ha in India, $1.5 \mathrm{~m}$ ha in Pakistan, $0.6 \mathrm{~m}$ ha in Bangladesh, and $0.5 \mathrm{~m}$ ha in Nepal [3]. There are about $9 \mathrm{~m}$ ha in China [4] of this cropping system. In this cropping system, rice is grown during rainy season (June to November) and wheat during the winter season (November to April). This is an intensive cropping system and its productivity varies from 5 to 10 metric tons of grains per hectare per year.

Agronomic management is the most important input for getting potential yield and high net returns in any crop or crop sequence. Rice-wheat is the most predominant cropping system of the northern plains of India. Most of the farmers used to grow old varieties of rice and wheat without any row arrangement. Fertilization is mainly limited to nitrogenous fertilizer only. Due to heavy depletion of plant nutrients, soils and the system show signs of fatigue, and there is a general decline in yield of rice and wheat [5] and a decrease in partial factor productivity of the fertilizer applied [6]. All of these together contribute to low productivity of crops. During 2008-2009, productivity of rice and wheat in Uttarakhand was $19.66 \mathrm{q} / \mathrm{ha}$ and $20.02 \mathrm{q} / \mathrm{ha}$, respectively, while it was $22.02 \mathrm{q} / \mathrm{ha}$ and $28.02 \mathrm{q} / \mathrm{ha}$ for the country as a whole during 2007-2008. Ratio of NPK use in the state has been $8.9: 2.4: 1$ during 2008-2009 instead of the recommended 4:2:1 [7].

Therefore, the present study was undertaken to find out the effect of different agronomic management practices (improved varieties, proper plant spacing, and balanced fertilization) on productivity and economics of rice-wheat system on the farmers' fields.

\section{Materials and Methods}

The experiment was conducted on farmers' fields, for four consecutive years from 2006-2007 to 2009-2010. Total of 
TABLE 1

\begin{tabular}{|c|c|}
\hline Treatment & Details of the treatment \\
\hline $\mathrm{T}_{1}$ & $\begin{array}{l}\text { Farmers' practices (in general, no line } \\
\text { sowing/transplanting, old varieties, and } \\
\text { imbalanced fertilizer use, i.e., very low or no } \\
\text { application of phosphorus and potassium) }\end{array}$ \\
\hline $\mathrm{T}_{2}$ & Farmers' practices except improved varieties \\
\hline $\mathrm{T}_{3}$ & $\begin{array}{l}\text { Farmers' practices except improved varieties and } \\
\text { proper plant spacing by line sowing/transplanting }\end{array}$ \\
\hline $\mathrm{T}_{4}$ & $\begin{array}{l}\text { Recommended practices, that is, improved } \\
\text { varieties, proper plant spacing by line } \\
\text { sowing/transplanting, and balanced fertilization }\end{array}$ \\
\hline
\end{tabular}

eighteen farmers were selected taking a single farmer as a replication from the six different blocks of district Dehradun and Pauri (Uttarakhand, India) for the study. Four treatments were evaluated in randomized block design; details of treatment are shown in Table 1.

Under the treatment $\mathrm{T}_{3}$ and $\mathrm{T}_{4}$ transplanting of rice was done at the spacing of $20 \times 10 \mathrm{~cm}$ while the wheat crop was sown at $23 \mathrm{~cm}$ row spacing. In treatment $\mathrm{T}_{4}$ the rice and wheat crops were fertilized as per the recommendations for the respective varieties. During the rainy season (kharif), rice was grown and during the succeeding winter season (rabi), wheat was grown under the rice-wheat cropping system continuously for four years of experimentation. During the rainy season, after taking the soil samples, the land was diced twice, flooded, and puddled several times; the land was then leveled and flooded before transplanting of rice seedlings. After rice harvest, the field was given a presowing irrigation where it was needed and when the soil came to condition, it was diced twice and leveled before sowing of wheat crop.

During 2006-2007, Pant Dhan 12 and PBW 343 were taken as improved varieties in rice and wheat, respectively, while during the next year, rice variety PR 113 and wheat variety UP 2572 were taken as improved ones. During 20082009, Pusa Sugandh 5 and PBW 502 were taken as improved varieties in rice and wheat, respectively, while during the next year, rice variety Pusa Sugandha 4 in district Dehradun and Pant Sankar Dhan 3 in district Pauri and wheat variety PBW 550 were taken as improved ones.

A uniform application of zinc sulphate @ $25 \mathrm{~kg}$ per hectare was done irrespective of treatments before transplanting of rice crop. The data was recorded on grain and straw yield. Cost of cultivation and gross returns were calculated as per the prevailing market prices of inputs and the produce. The rice equivalent yield was calculated on the basis of the average price of rice and wheat grain at eighteen locations during the year 2009-2010 in districts Pauri and Dehradun. The average price calculated for rice was $\$ 21 / \mathrm{q}$ and for wheat it was $\$ 22.1 /$ ha.

Soils of the experimental sites were analysed during all the years of experimentation before sowing of kharif crop. In general, the soils were medium in organic carbon, low in available nitrogen, and medium in available phosphorus and potassium.
The data was analysed statistically as per the procedure given by K. A. Gomez and A. A. Gomez [8]. The sustainability index was calculated using the formula as adopted by Gangwar et al. [9].

\section{Results}

The data of four years (2006 to 2010) was pooled together for the analysis and depicted in Tables 2, 3, and 4.

3.1. Rice. Inclusion of improved variety in farmers' practice (treatment $\mathrm{T}_{2}$ ) increased the grain yield ( $\left.4197 \mathrm{~kg} / \mathrm{ha}\right)$ significantly over the farmers' practice (treatment $\left.\mathrm{T}_{1}\right)(3941 \mathrm{~kg} / \mathrm{ha})$. When farmers' practice was practiced with improved variety along with transplanting in lines (treatment $\mathrm{T}_{3}$ ), it resulted in a significant increase in grain yield of rice $(594 \mathrm{~kg} / \mathrm{ha})$ over the farmers' practice (treatment $\mathrm{T}_{1}$ ).

Highest grain yield of rice $(5108 \mathrm{~kg} / \mathrm{ha})$ was recorded with the treatment $\mathrm{T}_{4}$ having all recommended management practices, that is, improved variety, transplanting in lines, and balanced fertilization, and it was significantly higher over the remaining management practices.

Again the highest straw yield $(6703 \mathrm{~kg} / \mathrm{ha})$ was recorded with the treatment $\mathrm{T}_{4}$ and it was superior to the rest of the treatments for the straw yield. Straw yield did not increase significantly over the farmers' practice by inclusion of improved variety alone, but it increased with the inclusion of improved variety along with $(5911 \mathrm{~kg} / \mathrm{ha})$ transplanting of rice in lines. However, when all recommended management practices were followed $\left(\mathrm{T}_{4}\right)$, the increase in straw yield was found to be significant over the rest of the treatments.

Cost of cultivation increased significantly by inclusion of improved variety in farmers' practice $\left(\mathrm{T}_{2}\right)$; however, cost of cultivation did not increase further when transplanting was done in lines along with the improved variety $\left(\mathrm{T}_{3}\right)$. Highest cost of cultivation ( $\$ 410$ per hectare) was observed with the treatment $\mathrm{T}_{4}$ having all recommended management practices, that is, improved variety, transplanting in lines, and balanced fertilization, and it was higher than the rest of the treatments.

Net and gross returns in rice crop increased significantly by the replacement of old varieties with the improved ones by $\$ 39$ and $\$ 47$ per hectare, respectively. When transplanting was done in lines using improved variety, it resulted in a significant increase of $\$ 57$ and $\$ 70$ per hectare of net and gross returns, respectively, over the treatment having improved variety but transplanting without row arrangement. Highest net and gross returns were recorded with the treatment $\mathrm{T}_{4}$ having all recommended management practices (\$572/ha and $\$ 981 /$ ha, resp.). The net and gross returns under this treatment were found to be significantly higher than the remaining treatments.

Use of improved rice variety incurred additional cost of cultivation of $\$ 9$ and provided additional net returns of $\$ 39$. When the rice crop was transplanted in lines, it incurred additional cost of cultivation by $\$ 13$ and provided additional net returns of $\$ 57 /$ ha. Balanced fertilization resulted in additional cost of cultivation by $\$ 22 /$ ha and provided 
TABLE 2: Grain and straw yield and economics of different agronomic management practices in rice crop (pooled data of four years).

\begin{tabular}{|c|c|c|c|c|c|c|c|}
\hline $\begin{array}{l}\text { Agronomic } \\
\text { management } \\
\text { practices }\end{array}$ & $\begin{array}{l}\text { Grain yield } \\
\text { (kg/ha) }\end{array}$ & $\begin{array}{l}\text { Straw yield } \\
\quad(\mathrm{kg} / \mathrm{ha})\end{array}$ & $\begin{array}{c}\text { Cost of cultivation } \\
\qquad\left(\$^{*} / \mathrm{ha}\right)\end{array}$ & $\begin{array}{l}\text { Net returns } \\
\quad(\$ / \text { ha })\end{array}$ & $\begin{array}{c}\text { Gross returns } \\
(\$ / \mathrm{ha})\end{array}$ & $\begin{array}{c}\text { Incremental } \\
\text { net returns }(\$ / \text { ha })\end{array}$ & B : C ratio \\
\hline $\mathrm{T}_{1}$ & 3941 & 5207 & 366 & 398 & 765 & - & 1.08 \\
\hline $\mathrm{T}_{2}$ & 4197 & 5478 & 375 & 437 & 812 & 39 & 1.16 \\
\hline $\mathrm{T}_{3}$ & 4535 & 5911 & 388 & 494 & 882 & 96 & 1.27 \\
\hline $\mathrm{T}_{4}$ & 5108 & 6703 & 410 & 572 & 981 & 173 & 1.39 \\
\hline SEm & 68 & 97 & 2 & 10 & 11 & - & - \\
\hline cd at $5 \%$ & 192 & 276 & 6 & 28 & 32 & - & - \\
\hline
\end{tabular}

$\$^{*}$ : US dollar and 1 US \$equals 53 Indian rupees.

TABLE 3: Grain and straw yield and economics of different agronomic management practices in wheat crop (pooled data of four years).

\begin{tabular}{|c|c|c|c|c|c|c|c|}
\hline $\begin{array}{l}\text { Agronomic } \\
\text { management } \\
\text { practices }\end{array}$ & $\begin{array}{l}\text { Grain yield } \\
\text { (kg/ha) }\end{array}$ & $\begin{array}{l}\text { Straw yield } \\
\quad(\mathrm{kg} / \mathrm{ha})\end{array}$ & $\begin{array}{c}\text { Cost of cultivation } \\
(\$ / \mathrm{ha})\end{array}$ & $\begin{array}{l}\text { Net returns } \\
\quad(\$ / \text { ha })\end{array}$ & $\begin{array}{l}\text { Gross returns } \\
(\$ / \text { ha })\end{array}$ & $\begin{array}{c}\text { Incremental } \\
\text { net returns }(\$ / \text { ha })\end{array}$ & B : C ratio \\
\hline $\mathrm{T}_{1}$ & 3203 & 4107 & 333 & 577 & 911 & - & 1.73 \\
\hline $\mathrm{T}_{2}$ & 3464 & 4387 & 347 & 639 & 986 & 62 & 1.84 \\
\hline $\mathrm{T}_{3}$ & 3802 & 4777 & 364 & 728 & 1092 & 151 & 1.99 \\
\hline $\mathrm{T}_{4}$ & 4254 & 5392 & 380 & 830 & 1210 & 252 & 2.18 \\
\hline SEm & 49 & 74 & 2 & 13 & 15 & - & - \\
\hline cd at $5 \%$ & 139 & 209 & 5 & 38 & 41 & - & - \\
\hline
\end{tabular}

additional net returns of $\$ 78$. Recommended package of practices, that is, improved variety, transplanting in lines, and balanced fertilization (treatment $\mathrm{T}_{4}$ ), incurred additional cost of cultivation of $\$ 44 /$ ha and provided additional net returns of $\$ 78 /$ ha over the farmers' practices.

Several other workers also reported that improved variety, transplanting in lines, and balanced fertilization resulted in higher grain and straw yield which in turn increased net and gross returns in rice crop $[10,11]$.

Highest B : C ratio (1.39) was recorded with the treatment $\mathrm{T}_{4}$ and it was followed by the treatments $\mathrm{T}_{3}(1.27), \mathrm{T}_{2}$ (1.16), and $\mathrm{T}_{1}$ (1.08).

3.2. Wheat. Grain as well as straw yield of wheat increased significantly when the improved variety of wheat was taken (treatment $\mathrm{T}_{2}$ ) in place of old varieties under farmers' practice (treatment $\mathrm{T}_{1}$ ). Grain as well as straw yields further increased significantly when the improved variety was sown in lines (treatment $\mathrm{T}_{3}$ ) over the broadcast sown improved variety (treatment $\mathrm{T}_{2}$ ). Highest grain and straw yields of wheat (4254 and $5392 \mathrm{~kg} / \mathrm{ha}$, resp.) were recorded when all recommended management practices were followed, that is, improved variety, line sowing, and balanced fertilization under the treatment $\mathrm{T}_{4}$ (Table 3).

Cost of cultivation of wheat crop increased significantly by use of improved variety in place of old variety by $\$ 14$, but it also provided significantly higher net returns by $\$ 62$ per hectare. Line sowing of wheat crop significantly increased the cost of cultivation by $\$ 17$ per hectare and it also resulted in significantly higher net returns by $\$ 151$ per hectare. Balanced use of fertilizers significantly increased the cost of cultivation by $\$ 16$ per hectare and provided significantly higher and additional net returns by $\$ 102$ per hectare.

Additional net returns of $\$ 47$ per hectare over the farmers' practice were recorded when all recommended management practices were followed, while the use of improved variety along with line sowing provided additional net returns of $\$ 31$ per hectare over the farmers' practice. Use of improved variety provided additional returns of $\$ 14 /$ ha over the farmers' practices.

Similar findings have also been reported that recommended package of practices resulted in higher mean grain yield and net returns compared to farmers practice [12]. Increased net and gross returns by use of improved variety, line sowing, and balanced fertilization have also been reported by other workers $[11,13]$.

Highest B : C ratio (2.18) was recorded with the treatment $\mathrm{T}_{4}$ and it was followed by treatment $\mathrm{T}_{3}$ (1.99), treatment $\mathrm{T}_{2}$ (1.84), and treatment $\mathrm{T}_{1}(1.73)$.

3.3. Rice-Wheat System. Lowest rice equivalent yield (REY) of rice-wheat system $(7311 \mathrm{~kg} / \mathrm{ha})$ was recorded with the farmers' practices. REY increased by $530 \mathrm{~kg} / \mathrm{ha}$ by inclusion of improved varieties in rice and wheat. Sowing/transplanting of rice and wheat in lines provided additional REY by $694 \mathrm{~kg} / \mathrm{ha}$. Balanced fertilization in rice-wheat system provided additional REY of $1048 \mathrm{~kg} / \mathrm{ha}$. Highest system productivity $(26.3 \mathrm{~kg} / \mathrm{ha})$ was recorded with the treatment having all recommended package of practices and the lowest with the farmers practice $(20.0 \mathrm{~kg} / \mathrm{ha} /$ year $)$. Inclusion of improved varieties in rice and wheat increased the system productivity up to the level of $21.5 \mathrm{~kg} / \mathrm{ha} /$ year. Use of improved varieties 
TABLE 4: Economics of rice-wheat system under different agronomic management practices (pooled data of four years).

\begin{tabular}{lcccccccc}
\hline $\begin{array}{l}\text { Agronomic } \\
\text { management } \\
\text { practices }\end{array}$ & $\begin{array}{c}\text { Rice equivalent } \\
\text { yield of the } \\
\text { system }(\mathrm{kg} / \mathrm{ha})\end{array}$ & $\begin{array}{c}\text { System } \\
\text { productivity } \\
(\mathrm{kg} / \mathrm{ha} / \text { day })\end{array}$ & $\begin{array}{c}\text { Cost of } \\
\text { cultivation } \\
(\$ / \mathrm{ha})\end{array}$ & $\begin{array}{c}\text { Net returns } \\
(\$ / \mathrm{ha})\end{array}$ & $\begin{array}{c}\text { Gross } \\
\text { returns } \\
(\$ / \mathrm{ha})\end{array}$ & $\begin{array}{c}\text { Incremental } \\
\text { net returns } \\
(\$ / \mathrm{ha})\end{array}$ & $\begin{array}{c}\text { B:C } \\
\text { ratio }\end{array}$ & $\begin{array}{c}\text { Sustainability } \\
\text { index }\end{array}$ \\
\hline $\mathrm{T}_{1}$ & 7311 & 20.0 & 670 & 976 & 1675 & - & 1.39 \\
$\mathrm{~T}_{2}$ & 7841 & 21.5 & 722 & 1076 & 1798 & 101 & 1.49 \\
$\mathrm{~T}_{3}$ & 8535 & 23.4 & 752 & 1222 & 1974 & 246 & 1.62 \\
$\mathrm{~T}_{4}$ & 9583 & 26.3 & 790 & 1402 & 2192 & 426 & 1.77 \\
SEm & - & - & 3 & 22 & 24 & -6.86 & 0.81 \\
cd at 5\% & - & - & 10 & 62 & 69 & - & - & - \\
\hline
\end{tabular}

along with sowing/transplanting in lines further increased the system productivity to $23.4 \mathrm{~kg} / \mathrm{ha} /$ year.

Cost of cultivation increased significantly by $\$ 52$ per hectare by the incorporation of improved varieties in farmers' practice, and it also resulted in significantly higher net and gross returns by $\$ 100 /$ ha and $\$ 123 /$ ha, respectively. Inclusion of line sowing/transplanting in rice-wheat system resulted in significantly increased cost of cultivation by $\$ 30 /$ ha only and it also resulted in significantly increased net and gross returns by $\$ 146 /$ ha and $\$ 176 /$ ha, respectively. The treatment having all the recommended management practices $\left(\mathrm{T}_{4}\right)$ had significantly higher cost of cultivation (\$790/ha) and net returns $(\$ 1402 / \mathrm{ha})$ over the rest of the treatments.

Inclusion of improved variety in rice and wheat incurred additional cost of $\$ 52 /$ ha and provided additional return of $\$ 101 /$ ha, whereas sowing/transplanting of rice and wheat in lines incurred additional cost of $\$ 30 /$ ha and resulted in additional returns of $\$ 146 /$ ha. Balanced fertilization costed more by $\$ 38 /$ ha over the imbalanced fertilization and provided additional returns of $\$ 180 /$ ha. Recommended package of practices (treatment $\mathrm{T}_{4}$ ) incurred additional cost of cultivation of $\$ 120 /$ ha over the farmers' practice and achieved additional net returns of $\$ 426 /$ ha. Incremental net returns of $\$ 246 /$ ha were recorded in treatment $\mathrm{T}_{3}$ having improved variety and line sowing/transplanting over the farmers' practice (treatment $\mathrm{T}_{1}$ ), whereas incremental net returns of $\$ 101 /$ ha were recorded in treatment $\mathrm{T}_{2}$ having the improved variety over the farmers' practice.

Highest B : C ratio of 1.77 was recorded with the treatment having all the recommended management practices and it was followed by treatment $\mathrm{T}_{3}$ (1.62) having improved variety and line sowing/transplanting with farmers' practice, treatment $\mathrm{T}_{2}$ (1.49) having improved varieties with farmers' practice, and treatment $\mathrm{T}_{1}(1.39)$ having farmers' practice.

Highest relative economic efficiency $(47.7 \%)$ of the ricewheat system was recorded with the treatment having all the recommended management practices, and it was followed by treatment $\mathrm{T}_{3}(25.3 \%)$ having improved varieties as well as line sowing/transplanting and treatment $\mathrm{T}_{2}$ (10.3\%) having improved varieties.

Treatment $\mathrm{T}_{4}$ having the improved variety, line sowing/transplanting, and balanced fertilization had a relative production efficiency $31.0 \%$. Treatments $\mathrm{T}_{2}$ and $\mathrm{T}_{1}$ also had positive figures of relative production efficiency of $16.7 \%$ and $7.2 \%$, respectively.
Sustainability index varied from 0.81 (treatment $\mathrm{T}_{4}$ ) to 0.88 (treatment $\mathrm{T}_{3}$ ). Treatment $\mathrm{T}_{1}$ and treatment $\mathrm{T}_{2}$ have sustainability index of 0.82 and 0.86 , respectively. So, not much variation between treatments for sustainability suggests less variation in sustainability between treatments.

\section{Conclusion}

The findings of the present study envisage that for feeding the ever growing population and to earn higher returns, farmers should adopt the recommended management practices for rice-wheat cropping system.

The management practices increased productivity and ultimately the returns from each incremental change, with the recommendation that adoption of some of the practices would result in increased yields and returns.

However, the resource poor and marginal farmers who cannot afford to adopt the full package of recommended management practices should go for as much as affordable management practices (improved varieties, proper spacing, and recommended fertilization).

\section{Conflict of Interests}

The authors declare that there is no conflict of interests regarding the publication of this paper.

\section{References}

[1] S. Fujisaka, L. Harrington, and P. Hobbs, "Rice-wheat in South Asia: systems and long-term priorities established through diagnostic research," Agricultural Systems, vol. 46, no. 2, pp.169$187,1994$.

[2] P. Hobbs, "Rice-wheat system in South Asia," in Proceeding of the Symposium, Sustainability of Rice-Wheat System in India, S. D. Dhiman, M. K. Chaudhary, D. V. S. Pawan, and K. S. Verma, Eds., pp. 61-76, CCS Haryana Agriculture University, Hissar, India, 1994.

[3] T. Woodhead, R. Huke, E. Huke, and L. Balababa, Rice-Wheat Atlas of India, IRRI/CIMMYT/ICAR, Los Banos, Philippines, 1994.

[4] R. E. Huke, T. Huke, Woodhead, and J. Huang, Rice-Wheat Atlas ofChina, IRRI/CIMMYT/CNRRI, Los Banos, Philippines, 1994.

[5] R. L. Yadav, D. S. Yadav, R. M. Singh, and A. Kumar, "Long term effects of inorganic fertilizer inputs on crop productivity in 
a rice-wheat cropping system," Nutrient Cycling in Agroecosystems, vol. 51, no. 3, pp. 193-200, 1998.

[6] R. L. Yadav, "Factor productivity trends in a rice-wheat cropping system under long-term use of chemical fertilizers," Experimental Agriculture, vol. 34, no. 1, pp. 1-18, 1998.

[7] Statistical Diary Uttarakhand 2008-09, Government of Uttarakhand, Dehradun, India, 2010.

[8] K. A. Gomez and A. A. Gomez, Statistical Procedure for Agriculture Research, Wiley, New York, NY, USA, 2nd edition, 1984.

[9] B. Gangwar, V. Katyal, and K. V. Anand, "Stability and efficiency of cropping systems in Chhattisgarh and Madhya Pradesh," Indian Journal of Agricultural Sciences, vol. 74, no. 10, pp. 521528, 2004.

[10] R. K. Bhagat, "Management of rice-chickpea cropping system under rainfed condition," Jounal of Research, vol. 14, no. 1, pp. 73-75, 2002.

[11] S. K. Sharma, K. Sharma, S. S. Rana, J. J. Sharma, and G. D. Sharma, "On farm evaluation of management practices of rice and wheat in sub montane low hills of Himachal Pradesh," Himachal Journal of Agricultural Research, vol. 33, no. 1, pp. 1-3, 2007.

[12] A. K. Pandey, V. Prakash, R. D. Singh, and H. S. Gupta, "Contribution and impact of production factors on growth, yield attributes, yield and economics of rainfed wheat (Triticum aestivum)," Indian Journal of Agronomy, vol. 46, no. 4, pp. 674681, 2001.

[13] R. S. Rinwa, S. C. Gupta, M. C. Mundra, and B. P. Singh, "Impact on production of predominant cropping systems with different inputs management in Haryana," Crop Research, vol. 25, no. 3, pp. $468-471,2003$. 


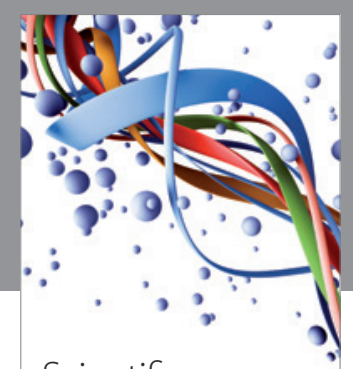

Scientifica
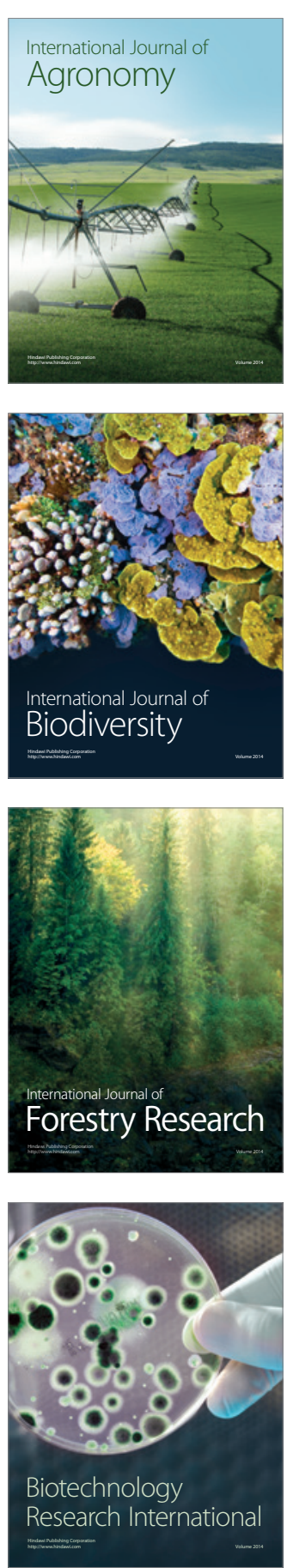
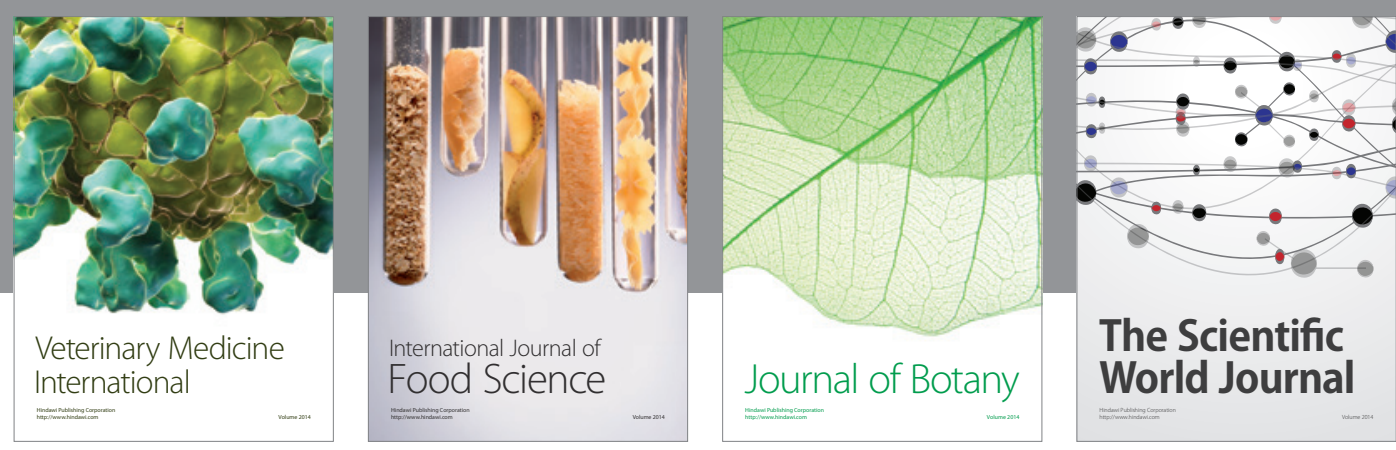

The Scientific World Journal
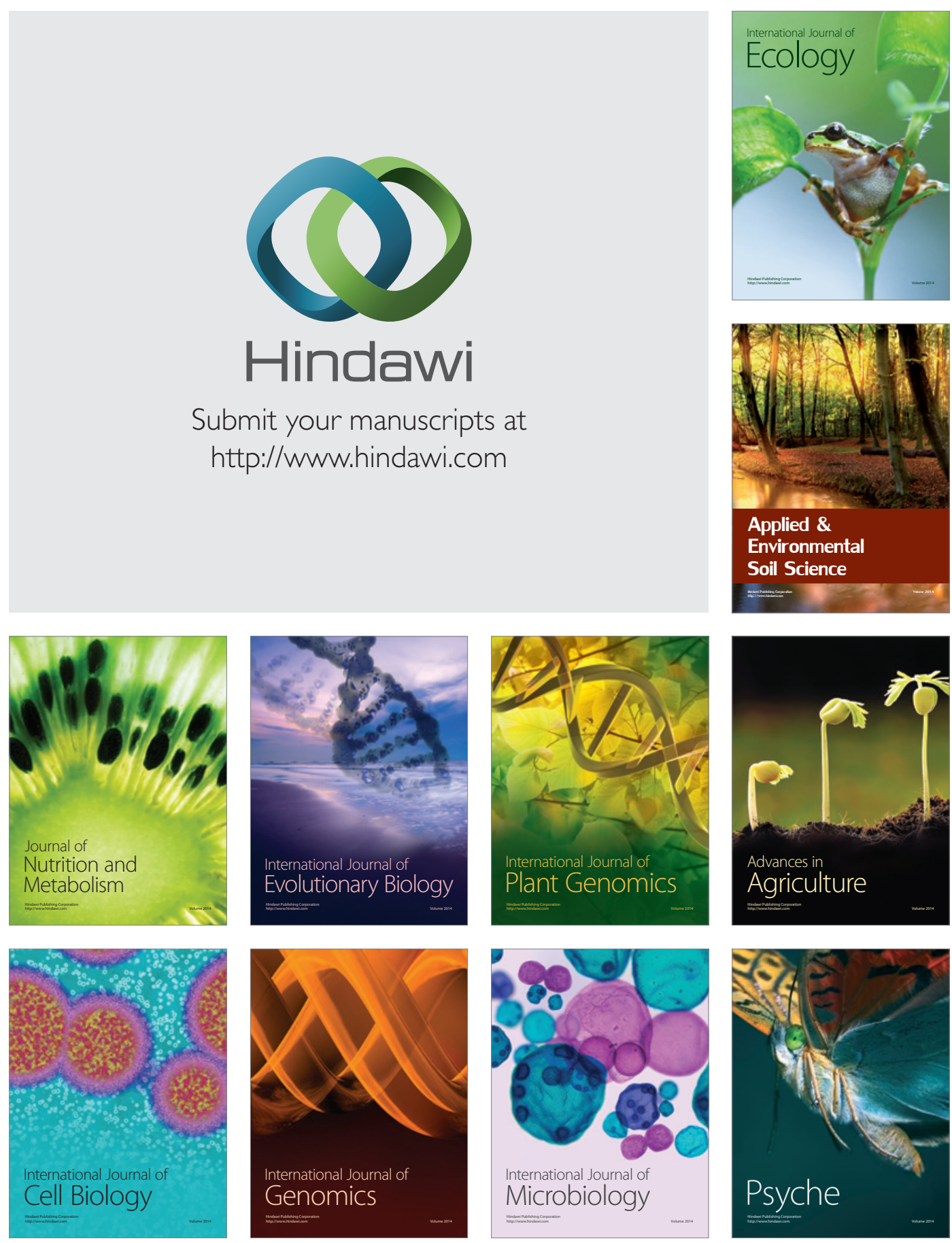